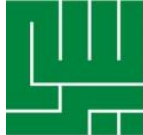

\title{
Pengaruh Penggunaan Media Belajar Quipper School Terhadap Minat Belajar Matematika Pada Siswa
}

\section{The Influence of Quipper School to the Interest of Learning Mathematics among Students}

\author{
Dwi Hurriyati ${ }^{1}$, Desy Arisandy ${ }^{2}$ \\ ${ }^{1,2}$ Fakultas Psikologi, Universitas Bina Darma Palembang \\ J1. A. Yani No. 12 Palembang \\ Email: dwi.hurriyati@binadarma.ac.id, desy.arisandy@binadarma.ac.id
}

\author{
KATA KUNCI Media Belajar, Quipper School, Minat Belajar \\ KEYWORDS Media Learning, Quipper School, Learning Interest.
}

\section{ABSTRAK}

ABSTRACT This study aims to determine the influence of quipper school to the interest of learning mathematics in students SMAN 15 Palembang. The hypothesis is the quipper school methods have a significant influence to enhance students' learning interest in mathematics. The subjects of this study are 90 students of SMAN 15 Palembang that hired by using purposive sampling. This study uses comparative two independent group test technique to prove the hypothesis. The result shows there is a significant change of interest after the learning method applied Quipper School in SMAN 15 Palembang $(t=-$ 8.669 and $p<0.05)$. This study also shows that there is a change of mathematics mark after enacted Quipper School learning media in SMA Negeri 15 Palembang $(t=$ 13.803, $p<0.05)$. Thus it can be concluded that the use of learning media Quipper School significant to increase the interest of learning mathematics in students SMAN 15 Palembang.

\section{PENDAHULUAN}

Penggunaan teknologi informasi dan komunikasi merupakan salah satu faktor yang memungkinkan kecepatan transformasi ilmu pengetahuan kepada peserta didik. Adanya media pembelajaran menuntut guru untuk mempersiapkan materi dengan matang. Pendidikan mampu berkembang ke arah yang lebih modern dengan mengikuti pembaharuan pembelajaran menggunakan teknologi di dalamnya terutama dalam pembelajaran matematika.

Pentingnya penguasaan dan banyaknya manfaat di bidang matematika membuat banyak pihak menaruh perhatian terhadap proses penguasaan matematika dalam konteks pendidikan. Semua pihak berupaya agar siswa dapat menguasai matematika dan dapat dimanfaatkan dan digunakan dalam kehidupan sehari-hari, Pelajaran matematika dianggap oleh 
sebagian siswa sebagai pelajaran yang sulit dan menakutkan. Karakteristik matematika yang abstrak dan sistematis menjadi salah satu alasan sulitnya siswa mempelajari matematika serta menjadikan kurang berminat dalam mempelajarinya.

Firngadi (1997) menambahkan bahwa matematika merupakan salah satu pelajaran yang menurunkan semangat siswa. Matematika telah diberi label negatif dikalangan sebagaian siswa, yaitu sebagai pelajaran yang sulit, menakutkan, dan membosankan, sehingga menimbulkan minat yang rendah untuk belajar. Agar image negative pada sebagian siswa pelajaran matematika dapat berkurang, maka dibutuhkan ketertarikan dan rasa senang siswa dalam mempelajari matematika, yang sering disebut dengan minat belajar matematika.

Minat menurut Slameto (dalam Hamalik, 2010), adalah suatu rasa lebih suka dan rasa ketertarikan pada suatu hal atau aktifitasnya, tanpa ada yang menyuruh. Minat belajar menurut Slameto (2010) adalah rasa suka ketertarikan pada suatu pelajaran atau aktivitas tanpa ada yang menyuruh, minat pada hakekatnya adalah penerimaan hubungan antara diri sendiri dengan sesuatu diluar dirinya, semakin kuat atau semakin dekat hubungan tersebut maka semakin besar minatnya.

Pada proses belajar mengajar, dua unsur yang amat penting adalah metode mengajar dan media pembelajaran. Pemilihan salah satu metode mengajar tentu akan mempengaruhi jenis media pembelajaran yang sesuai. Hamalik (dalam Arsyad, 2016) mengemukakan bahwa pemakaian media pembelajaran dalam proses belajar mengajar dapat membangkitkan keinginan dan minat baru, membangkitkan motivasi dan rangsangan kegiatan belajar, bahkan membawa pengaruh-pengaruh psikologis terhadap siswa. Penggunaan media pembelajaran pada tahap orientasi pembelajaran akan sangat membantu keefektifan proses pembelajaran dan penyampaian pesan dan isi pelajaran pada saat itu. Selain membangkitkan motivasi dan minat siswa, media pembelajaran juga dapat membantu siswa meningkatkan pemahaman, menyajikan data dengan menarik dan terpercaya, memudahkan penafsiran data, dan memadatkan informasi.

Salah satu media pembelajaran yang terbukti efektif dalam meningkatkan minat belajar adalah quipper school. Quipper school merupakan platform penghubung antara siswa dan guru dalam pembagian tugas secara online (Lingga, 2016). Layanannya diklaim sesuai dengan pelajaran yang diadaptasi dari kurikulum yang berlaku di Indonesia, mata pelajaran yang umum ditemukan seperti Bahasa Indonesia, Bahasa Inggris, Matematika, IPA, dan IPS tersedia di dalam quipper school.

Penulis tertarik untuk memilih fokus pada mata pelajaran matematika karena sering kita lihat dan kita saksikan bahwa mata pelajaran matematika merupakan salah satu pelajaran yang sebagian siswa tidak menyukainya, sehingga penulis tertarik untuk meneliti pengaruh penggunaan metode pembelajaran quipper school pada mata pelajaran matematika. Sesuai dengan keterangannya, saat ini, quipper school hanya bisa diberikan oleh siswa kelas SMA mulai dari kelas 10 hingga kelas 12. Di dalam aplikasi quipper school terdapat materi pelajaran dan soalsoal yang tersedia dan bisa menjadi bahan materi pelajaran tambahan untuk siswa.

Media pembelajaran quipper school memberikan banyak manfaat. Akan tetapi, penggunaannya juga membutuhkan dukungan, seperti kemampuan dan pengetahuan seseorang untuk menggunakan komputer atau laptop dalam mengakses internet. Selain itu, metode ini juga membutuhkan dukungan jaringan yang stabil untuk proses penggunaan pembelajaran quipper school.

SMAN 15 Palembang merupakan salah satu sekolah yang menggunakan media pembelajaran quipper school pada beberapa mata pelajaran dalam proses belajar siswa, Penulis ingin meneliti hal ini 
karena quipper school merupakan suatu aplikasi terobosan baru dalam media pembelajaran secara online yang sejalan dengan perkembangan teknologi yang semakin pesat. Hipotesis dalam penelitian adalah terdapat pengaruh penggunaan media pembelajaran quipper school terhadap minat belajar matematika pada siswa SMAN 15 Palembang.

\section{METODE PENELITIAN}

Metode yang akan digunakan untuk mengumpulkan data pada penelitian ini adalah metode quasi eksperimen dengan skala sebagai alat pengumpul data. Skala adalah perangkat peryataan yang disusun untuk menggungkap atribut tertentu melalui respon terhadap peryataan tersebut (Azwar, 2012).

Minat belajar diukur dengan menggunakan skala minat belajar yang disusun sendiri oleh peneliti dengan mengacu pada indikator minat belajar menurut Slameto (2010) yaitu: (a) memiliki perhatian yang besar, untuk mencapai hasil belajar yang baik, maka siswa harus mempunyai perhatian terhadap bahan yang dipelajarinya, jika bahan atau materi pelajaran tidak menjadi perhatian siswa, maka minat belajar pun rendah, (b) memiliki harapan yang tinggi, merupakan suatu yang dapat dibentuk dan dapat digunakan sebagai langkah untuk perubahan, perubahan yang menguntungkan dapat menyebabkan individu mencapai hidup yang lebih baik, (c) berorientasi pada keberhasilan, individu mampu mengelola kemampuan secara realitas dan cermat untuk mencapai tujuan yang berkaitan dengan pelaksanaan tugas dan peningkatan prestasi di kemudian hari, (d) mempunyai kebanggaan, merupakan adanya perasaan puas pada diri sendiri dari apa yang didapat melalui hasil belajar, individu yang mendapatkan hasil yang baik dari kegiatan belajar, akan mempunyai kebanggaan tersendiri dalam dirinya, serta (e) kesediaan untuk berusaha, individu dalam proses belajar memiliki keinginan untuk berusaha sesuai dengan kemampuan untuk mencapai hasil belajar yang optimal. Skala minat belajar disajikan dalam 46 pernyataan yang berupa pernyataan yang mendukung (favourable) dan pernyataan yang tidak mendukung (unfavourable), yang harus dijawab subjek dengan berdasarkan 5 kategori jawaban yang telah disediakan yaitu Setuju (S), Sangat Setuju (SS), Netral (N), Tidak Setuju (TS), dan Sangat Tidak Setuju (STS).

Adapun populasi dalam penelitian ini adalah siswa SMA Negeri 15 Palembang sebanyak 90 orang dari kelas X dan kelas XI. Sementara itu, untuk kelas XII tidak dijadikan populasi karena fokus akan menghadapi ujian nasional. Dengan demikian, partisipan dalam penelitian ini hanya siswa kelas $\mathrm{X}$ dan kelas $\mathrm{XI}$. Pemilihan sampel dalam penelitian ini menggunakan purposive sampling. Menurut Sugiono (2007), purposive sampling yaitu tekhik penentuan sampel dengan pertimbangan tertentu atau berdasarkan kriteria tertentu. Adapun kriteria sampel penelitan ini adalah siswa yang memiliki nilai rata-rata ulangan berkisar antara 6570. Hal ini dilakukan untuk pengkondisian kelompok kontrol dan eksperimen agar memiliki kemampuan matematika yang sama.

Berdasarkan ciri-ciri dan dilihat dari kriteria yang ditentukan diatas, didapatkan 90 orang yang bersedia mengikuti penelitian ini hingga selesai. Oleh karena itu sampel yang digunakan dalam penelitian ini yaitu sebanyak 90 orang yang terbagi menjadi 45 orang untuk kelompok eksperimen dan 45 orang untuk kelompok kontrol.

Teknik pengumpulan data dan instrument penelitian yang digunakan adalah tes, observasi, dokumentasi, wawancara, dan kuesioner (angket). Tes dalam penelitian berupa soal pilihan ganda. Observasi dilakukan untuk mengetahui fenomena awal subyek penelitian. Angket digunakan untuk mengetahui seberapa besar minat belajar matematika, angket yang 
digunakan dalam penelitian ini berbentuk checklist dengan menggunakan skala Likert.

Desain yang digunakan dalam penelitian ini adalah dua kelompok yaitu Kelompok Eksperimen (KE) dan Kelompok Kontrol (KK). Desain dua kelompok merupakan desain yang bersifat eksploratif, karena dengan demikian dapat diketahui apakah VB berpengaruh terhadap VT. Pengaruh VB terhadap VT dibuktikan dengan memberikan VB kepada satu kelompok (yang disebut kelompok eksperimen) dan tidak memberikan VB terhadap kelompok lain (yang disebut kelompok kontrol).

Penelitian ini menggunakan desain pre-posttest control group design. Pada penelitian dengan desain ini, peneliti harus melakukan randomisasi dan melakukan tes sebelum dan sesudah perlakuan pada kelompok eksperimen dan kelompok kontrol. Peneliti telah melakukan randomisasi dengan cara memilih secara acak dari 90 partisipan yang sesuai kriteria dan memasukkannya ke dalam kelompok eksperimen dan kontrol. Kriteria yang siswa yang memiliki nilai rata-rata ulangan berkisar antara 65-70. Hal ini dilakukan untuk pengkondisian kelompok kontrol dan eksperimen agar memiliki kemampuan matematika yang sama.

Pretest dilakukan pada kedua kelompok dengan menggunakan skala minat belajar sebelum pelatihan dilakukan. Posttest dilakukan pada kedua kelompok (KK dan KE) tepat setelah pelatihan selesai dilakukan dan 14 hari setelah pelatihan untuk melihat efek jangka panjang dari pelatihan.

Penelitian ini menggunakan teknik uji t yaitu uji-t 2 kelompok independen (independent t-test) untuk menguji hipotesa penelitian. Teknik ini digunakan untuk melihat efektivitas atau pengaruh metode pembelajaran quippers school terhadap minat belajar matematika siswa SMAN 15 Palembang dilihat dari perbedaan antara skor kelompok kontrol dan kelompok eksperimen setelah perlakuan selesai diberikan.

\section{ANALISIS \& HASIL}

Berdasarkan analisis uji normalitas dengan menggunakan KolmogorovSmirnov, hasil untuk KK adalah KS-Z= 1,477 dan $p=0,025$, sehingga $p>0,05$ sedangkan hasil $\mathrm{KE}$ adalah $\mathrm{KS}-\mathrm{Z}=1,273$ dan $p=0,078$, sehingga $p>0,05$, maka data $\mathrm{KK}$ dan KE dapat dikatakan terdistribusi normal.

Uji homogenitas menggunakan teknik independent sampel t-test dengan program SPSS.20. Hasil yang diperoleh adalah $\mathrm{F}=0,636$, sedangkan nilai $\mathrm{p}=0,427$ $(p>0,05)$. Hal ini berarti bahwa varians kelompok-kelompok yang dibandingkan tidak berbeda; artinya homogen.

Data awal sebelum diberikan perlakuan pada media quipper school, minat belajar matematika SMA Negeri 15 Palembang dapat diketahui siswa kurang berminat dalam mengikuti pelajaran matematika. Dari nilai rata-rata kelompok ekperimen yang berjumlah 45 siswa yaitu 38,72 dengan nilai terbesar 50 dan nilai terkecil 20. Sedangkan hasil rata-rata dari kelompok kontrol yang berjumlah 45 siswa yaitu 30,56, dengan nilai terbesar 40 dan nilai terkecil 20. Nilai rata-rata pretest kedua kelas terbilang jauh dari kriteria ketuntasan minimal, dimana nillai yang ditentutkan yaitu 7,5.

Dari data perhitungan analisa deskriptif dapat diketahui bahwa sebelum menggunakan media quipper school dari 45 siswa terdapat 5 siswa yang memiliki minat belajar matematika yang tinggi, 9 siswa memiliki minat belajar matematika yang cukup dan 31 siswa yang kurang memiliki minat belajar terhadap matematika. Terdapat juga nilai skor rata-rata minat belajar terhadap pelajaran matematika siswa dikelas tersebut $74,3 \%$. Artinya masih banyak siswa yang kurang berminat dalam pelajaran matematika. 
Tabel 1.

Hasil Uji Hipotesis

\begin{tabular}{llll}
\hline Kelompok & Sig & Mean & SD \\
\hline Kontrol & 0,019 & 140,64 & 28,55 \\
Eksperimen & 0,019 & 154,51 & 26,539 \\
\hline
\end{tabular}

Hasil dari dua kelompok t-test menunjukkan bahwa ada perbedaan antara kelompok control $(\mathrm{M}=140,64 ; \mathrm{SD}=28,55$, Sig $=0,019)$ dan kelompok Eksperimen $(\mathrm{M}=154,51 ; \mathrm{SD}=28,55 ; \mathrm{Sig}=0,019)$

Hasil uji hipotesis dilakukan pada hasil skor yang diperoleh kelompok kontrol dan kelompok eksperimen. Analisis statistik yang digunakan dalam penelitian ini adalah uji hipotesis dengan menggunakan teknik uji t yaitu uji-t 2 kelompok independen (independent $t$-test). Hasil analisis data penelitian pada pair 1 menunjukan nilai $\mathrm{t}=$ - 8,669 dan sig $=0,00$, artinya ada perubahan minat yang signifikan setelah diberlakukan metode belajar Quipper School di SMA 15 Palembang. Data penelitian pada pair 2 menunjukkan nilai $\mathrm{t}=$ $-13,803$ dan sig $=0,00$, artinya ada perubahan nilai matematika setelah diberlakukan media belajar Quipper School di SMA 15 Palembang. Dengan demikian dapat disimpulkan bahwa ada pengaruh penggunaan media belajar quipper school yang signifikan terhadap minat belajar matematika pada siswa SMAN 15 Palembang.

\section{DISKUSI}

Berdasarkan hasil penelitian tentang minat belajar siswa SMA N 15 Palembang sebelum menggunakan media quipper school dalam pembelajaran matematika. Diketahui bahwa minat siswa kurang terhadap pelajaran matematika, hal ini terlihat dari data perhitungan analisa deskriptif dapat diketahui bahwa sebelum menggunakan media quipper school dari 45 siswa terdapat 5 siswa yang memiliki minat belajar matematika yang tinggi, 9 siswa memiliki minat belajar matematika yang cukup dan 31 siswa yang kurang memiliki minat belajar terhadap mateamtika. Terdapat juga nilai skor rata-rata minat belajar terhadap pelajaran matematika siswa dikelas tersebut 74,3\%. Artinya masih banyak siswa yang kurang berminat dalam pelajaran matematika. Hal ini disebabkan karena beberapa faktor, seperti masih terdapatnya pembelajaran dengan menggunakan metode pembelajaran ceramah yang memerlukan komunikasi dua arah; dimana guru dalam menyampaikan materi harus dapat dimengerti oleh siswa sehingga siswa dapat mengerjakan soal hitungan yang diberikan. Hal inilah terkadang membuat siswa sering kali salah mempersepsikan apa yang dijelaskan oleh guru dan sulit untuk mengulangi kembali apa yang sudah disampaikan oleh gurunya. Dengan demikian, ketika guru memberikan soal siswa kurang memahami apa yang akan dikerjakannya. Karena itu perlu adanya metode baru dalam melakukan belajar matematika, salah satunya melalui media elektronik yaitu quipper school. Berdasarkan data awal sebelum diberikan media quipper school, nilai rata-rata kelompok ekperimen yang berjumlah 45 siswa yaitu 38,72 dengan nilai terbesar 50 dan nilai terkecil 20. Sedangkan hasil ratarata dari kelompok kontrol yang berjumlah 45 siswa yaitu 30,56, nilai terbesar 40 dan nilai terkecil 20. Nilai rata-rata pretest kedua kelas terbilang jauh dari kriteria ketuntasan minimal, dimana nilai yang ditentutkan yaitu 7,5.

Hasil penelitian menunjukkan bahwa kelompok eksperimen yang mendapat perlakuan melalui media quipper school memiliki minat belajar matematika lebih tinggi dibandingkan dengan kelompok kontrol yang tidak mendapatkan perlakuan, ini terlihat dari hasil perhitungan skor ratarata minat belajar matematika kelompok eksperimen $90,12 \%$, sedangkan skor ratarata minat belajar matematika kelompok kontrol sebesar 63,43\%. Perbedaan tersebut juga diukur melalui teknik uji t. Hasil analisis data penelitian pada kelompok eksperimen menunjukan nilai $\mathrm{t}=$ 
- 8,669 ( $\mathrm{p}=0,00<0,05)$, artinya ada perubahan minat yang signifikan setelah diberlakukan metode belajar Quipper School di SMA 15 Palembang. Data penelitian pada kelompok kontrol menunjukkan nilai $\mathrm{t}=-13,803$ dan sig $=$ 0,00 , artinya ada perubahan nilai matematika setelah diberlakukan media belajar Quipper School pada kelompok eksperimen dan minat belajar sisws di SMA 15 Palembang lebih tinggi. Sedangkan kelompok kontrol tidak menggunakan media Quipper School tidak ada perubahan pada nilai matematika dan minat belajar matematika juga tidak ada. Ini terlihat dari nilai kelompok eksperimen memiliki ratarata lebih besar $(M=154,51$ dan $\mathrm{SD}=$ 26,539) dibandingkan rata-rata kelompok kontrol $(M=140,64$ dan $\mathrm{SD}=28,555)$. Dengan demikian dapat disimpulkan bahwa ada pengaruh penggunaan media belajar quipper school yang signifikan terhadap minat belajar matematika pada siswa SMAN 15 Palembang.

Minat belajar siswa SMAN 15 terlihat berbeda pada saat belajar matematika antara belajar dengan metode biasa dan belajar dengan menggunakan media belajar quipper school, terlihat siswa yang belajar dengan metode biasa mereka terlihat tidak semangat belajar dan kurang memperhatikan buku pelajarannya, dan ketika mengerjakan soal latihan terlihat selalu ada keinginan menyontek kepada teman. Terdapat perbedaan minat belajar pada siswa yang menggunakan media belajar quipper school. Hal ini bisa dilihat pada proses belajar yang menyenangkan bagi mereka karna didalam fitur media belajar quipper school ini sangat banyak dan tidak membuat bosan saat belajar, minat belajar siswa terlihat dengan adanya motivasi belajar siswa yang baik dengan menggunakan media belajar quipper school ini sebagai media tambahan dalam belajar. Hal ini terlihat ketika peneliti yang dilakukan melakukan observasi mengenai nilai-nilai harian siswa sebelum diberikan media pembelajaran quipper school. Dimana nilai mereka antara 65-70, setelah diberikan media belajar quipper school nilai matematika berkisar antara 85-100.

Hamalik (Arsyad, 2016)

menjelaskan bahwa pemakaian media pembelajaran dalam proses belajar mengajar dapat membangkitkan keinginan dan minat baru, membangkitkan motivasi dan rangsangan kegiatan belajar. Menurut Sadiman (2014), penggunaan media pendidikan secara tepat dan bervariasi dapat mengatasi sikap pasif anak didik, dalam hal ini media pendidikan berguna untuk a) menimbulkan kegairahan belajar, b) memungkinkan interaksi yang lebih langsung antara anak didik dengan lingkungan dan kenyataan, serta c) memungkinkan anak didik belajar sendirisendiri menurut kemampuan dan minatnya.

Siswa SMA 15 Palembang terlihat memiliki perhatian yang besar pada saat belajar kondisi ini terlihat dari keseriusan siswa saat mempelajari materi-materi yang ada didalam media belajar quipper school, dan mempunyai harapan yang besar dalam mendapatkan nilai matematika yang baik dan memuaskan dengan kemampuankemampuan yang mereka miliki serta semangat dan usaha siswa sangat tinggi ketika belajar dengan media quipper school. Contoh ketika mereka mengerjakan soal matematika mereka harus hati-hati menjawab soal karena media belajar ini akan langsung menskoring jawaban siswa benar atau salah, ketika soal sudah selesai dikerjakan media belajar quipper school akan mengeluarkan nilai akhir siswa tersebut berupa skor yang akan diperoleh selama menyelesaikan tugas periode itu. Kondisi ini memicu motivasi dan semangat siswa dalam belajar lebih baik lagi ketika menggunakan media belajar quipper school serta menimbulkan minat belajar yang lebih baik. Quipper school merupakan penghubung antar siswa dan guru dalam pembagian tugas mata pelajaran secara online dan sesuai dengan mata pelajaran yang diadaptasi dari kurikulum yang diterapkan di Indonesia, yaitu IPS, IPA, Matematika dan Bahasa. Quipper school memberikan kemudahan bagi guru untuk 
mengirim tugas ke perangkat mobile yang dimiliki oleh siswa. Selain itu, guru dapat memantau perkembangan belajar siswanya secara online. Manfaat bagi siswa yaitu quipper school dapat digunakan sebagai media untuk mengerjakan tugas yang diberikan guru, mengakses seluruh materi pelajaran, dan mengirimkan pesan kepada guru mengenai kesulitan belajar yang dihadapi (Lingga, 2016). Kemudian menurut keterangan dari salah satu guru yang juga seringkali menggunakan media pembelajaran quipper school sebagai media komunikasi dan pemberian bahan pelajaran tambahan bagi siswa bahwa menurut penyampaian salah satu guru pengajar di sekolah bahwa dengan adanya media pembelajaran quipper school siswa merasa terbantu untuk melaksanakan pembelajaran, dan terkadang siswa yang remedial biberikan soal melalui media pembelajaran quipper school dan siswa merasa terbantu dan perbedaan nilai menggunakan media pembelajaran quipper school dengan metode biasa ada perbedaan. Data hasil penelitian menunjukkan ada peningkatan nilai matematika siswa SMA 15 Palembang setelah belajar menggunakan media Quipper School.

Keterbatasan dalam penelitian ini terletak pada kondisi jaringan yang terkadang bermasalah dan tidak bisa memberikan jaringan wi-fi yang maksimal oleh karena itu terkadang proses penggunaan quipper school mengalami hambatan dalam koneksi jaringan, maka hal ini harus menjadi perhatian penting dalam melakukan penelitian berbasis online. Jika pembelajaran dikolaborasikan dengan media pembelajaran terbaru ini dengan peningkatan teknologi informasi dan komunikasi dengan pengetahuan yang semakin meningkat dan tidak menutup kemungkinan menjadikan minat siswa dalam belajar bisa lebih baik.

\section{SIMPULAN}

Berdasarkan hasil penelitian dapat disimpulkan bahwa ada pengaruh media pembelajaran quipper school terhadap minat belajar metematika siswa SMAN 15 Palembang

\section{SARAN}

Saran praktis yang dapat diajukan peneliti untuk siswa SMAN 15 Palembang adalah agar dapat memanfaatkan media pembelajaran yang ada sebagai salah satu cara dalam menemukan proses belajar tambahan yang lebih baik lagi dan maksimal. Selain itu, guru dapat mengkolaborasikan media pembelajaran quipper school sebagai media pembelajaran tambahan dan terbaru dengan metode pembelajaran biasa, yang dilaksanakan lebih baik dan lebih aktif lagi setiap pekannya.

\section{DAFTAR PUSTAKA}

Arsyad, A. (2016). Media Pembelajaran. Jakarta: Rajawali Pers.

Astuti, M. (2001). Hubungan antara persepsi terhadap pembelajaran kontekstual dengan minat belajar matematika pada siswa kelas VII SMP Negeri 18 Semarang (Skripsi, Universitas Diponegoro, Semarang). Diunduh dari http://eprints.undip.ac.id/24784/.

Azwar, S. (2012). Sikap Manusia Teori dan Pengukurannya. Yogyakarta: Pustaka Pelajar.

Firngadi. (1997). Mengatasi Gangguan Belajar Pada Anak. Kliping Pendidikan. Salatiga: UKSW.

Hamalik, O. (2010) Proses Belajar Mengajar. Jakarta: PT Bumi Aksara

Lingga, M. (2016). Pengaruh penggunaan media pembelajaran quipper school terhadap hasil belajar siswa kelas VIII mata pelajaran matematika di SMP Negeri 4 Semarang (Skripsi, Universitas Negeri Semarang, Semarang). Diunduh dari

https://lib.unnes.ac.id/24056/1/11024120 $\underline{52 . p d f}$. 
Sadiman, A. S. (2014). Media Pendidikan Pengertian, Pengembangan dan Pemanfaatannya. Jakarta: Rajawali Pers.

Slameto. (2010). Belajar dan Faktor-Faktor yang Mempengaruhinya. Jakarta: Rineka Cipta. 